Research Article

\title{
Macroinvertebrate assemblages in mountain tributaries of glacial-fed and rain-fed rivers in eastern Nepal
}

\author{
Smriti Gurung ${ }^{1, *}$, Rashmi Singh ${ }^{1}$ Bisrantee Wagle ${ }^{1}$, Bibhuti Ranjan Jha ${ }^{1}$, Kumar Khatri $^{2}$, Dean Jacobsen ${ }^{3}$ \\ ${ }^{1}$ Department of Environmental Science and Engineering, Kathmandu University, Nepal \\ ${ }^{2}$ Mahendra Ratna Campus, Tribhuvan University, Nepal. \\ ${ }^{3}$ Freshwater Biological Section, Department of Biology, University of Copenhagen, Denmark \\ (Received: 11 July 2021; Revised: 21 November 2021; Accepted: 15 December 2021)
}

\begin{abstract}
While river macroinvertebrates are the most widely used form of bioindicators, their baseline information, although crucial, is scarce in Nepal. The main objective of this study was to assess the macroinvertebrate assemblages in mountain tributaries of the glacial-fed Tamor and rain-fed Kamala rivers. A total of eight sites were sampled during March 2015 (Spring), November 2015 (Autumn), January 2016 (Winter), and May 2016 (Summer). Altogether, 49 Families of macroinvertebrates belonging to 15 Orders were identified with 39 Families and 12 Orders in Tamor's tributaries, and 33 Families and 10 Orders in Kamala's tributaries. Nonmetric multi-dimensional scaling (NMDS) revealed different assemblages between the two river systems. The most dominant Order in the Tamor was Ephemeroptera and it was Trichoptera in the Kamala. EPT (Ephemeroptera Plecoptera Trichoptera) assemblages were the most abundant in all four seasons for both the river systems and higher \% EPT in Tamor's tributaries indicate better water quality than in the Kamala's tributaries. Typical cold water adapted Families such as Rhyacophilidae and Stenopsychidae were observed in Tamor's tributaries whereas in Kamala's tributaries, warm water adapted Families like Naididae and Thiaridae were found, reflecting a difference in the abiotic variables such as temperature, dissolved oxygen attributed to each of the catchments. This baseline data can serve as the foundation for further bioassessment including those of climate change impacts on aquatic biodiversity.
\end{abstract}

Keywords: EPT-taxa, glacial-fed tributaries, macroinvertebrates, rain-fed tributaries

\section{Introduction}

Tributaries are important features of any river system serving a multitude of ecosystem services. Tributaries connect different rivers and watersheds thereby forming passageways for nutrient transport, organic and inorganic matter; provide unique habitats to aquatic biota and often act as spawning sites and refuges for these organisms (Rice et al., 2008). Mountain rivers and their tributaries exhibit tremendous variation across spatio-temporal scales attributed to differences in their origin, tectonics, watershed geology and size, landuse, connectivity, hydrology etc. (Wohl, 2010). These differences in turn result in a range of different river physical and chemical parameters and aquatic biota.

Nepal with its distinct physiographic zones has large numbers of rivers and streams and the country's river systems can be broadly classified into three types based on their origin (WECS, 2011) - those arising from the glaciers and snow-fed lakes in Himalaya and Trans-Himalaya; those arising from the Mahabharat ranges (1000 -3000 masl) and those arising from the Chure Hills (200 -1000 masl). Accordingly, the biotic communities are likely to vary in these lotic systems. For instance, the headwaters of glacial-fed and rain-fed rivers exhibit distinctive climatic, geologic and riparian conditions, affecting abiotic parameters like hydrology, temperature, food sources and water chemistry (Espinosa et al., 2020; Jacobsen, 2009; Laursen et al., 2015), which ultimately have an impact on the abundance and diversity of the different biotic assemblages present (Meyer et al., 2007). Rain-fed headwaters are often characterized by forested catchments and biological communities in such forested headwaters primarily comprise heterotrophic organisms because of the lower photosynthesis/respiration ratio attributed to the shading effect (Vannote et al., 1980).

Benthic macroinvertebrates encompassing a rich taxonomic diversity of Arthropods, Annelids, Molluscs, Nematodes and Turbellarians (Hauer \& Resh, 2017; Heino, 2005) are important freshwater heterotrophic groups acting as linkages between the producers and higher level consumers (Wallace \& Webster, 1996). Their community structures differ along the longitudinal gradient of lotic systems, reflecting the difference in abiotic variables such as temperature (Suren, 1994), flow (LeCraw \& Mackereth, 2010), and available food sources (Mantyka-Pringle et al., 2014). In the upper reaches of forested mountain rivers, this group of organisms is often dominated by functional feeding group of shredders and collectors, primarily attributed to the presence of allochthonous coarse particulate organic matter (CPOM) which forms the principal food component (Cummins, 1974).

Macroinvertebrates are frequently used in the bioassessment of water bodies and watersheds because of their ability to reflect a range of environmental changes (Eriksen et al., 2021; Ofenböck et al., 2010). They have been used as bioindicators in a large number of studies to track changes in aquatic systems (Korte et al., 2010, Tamiru et al., 2017), particularly in streams and rivers (Buss et al., 2002; Patang et al., 2018). A number of macroinvertebrate-based indices and scores have been 
developed in many countries for water quality assessment and monitoring programmes (Metcalfe, 1989). Likewise, in Nepal, with the development of macroinvertebrate-based ecological assessment tool -NEPBIOS (Nepalese Biotic Score) (Sharma, 1996), these organisms have been frequently used to assess the impact of a range of stressors (Gurung et al., 2013; Sharma et al., 2005; Sharma et al., 2009). However, macroinvertebrate baseline studies in the country are still scarce and sporadic (Rundle et al., 1993; Suren, 1994), with a majority of these being concentrated in the western and central regions of Nepal (e.g., Gurung et al., 2013; Matangulu et al., 2017; Shah \& Shah, 2012; Shah et al., 2020a, 2020b). Studies in the eastern region are scarce (Jha et al., 2015; Poudel et al., 2014) despite the region being a biodiversity hotspot (IUCN, 2016). Therefore, the main objective of this study is to generate baseline information on the macroinvertebrate assemblages of selected tributaries of the Tamor River (glacial-fed) and the Kamala River (rain-fed) of eastern Nepal.

\section{MATERIALS AND METHODS}

Study area

This study was conducted in selected tributaries of two major rivers - Tamor and Kamala - in Taplejung, Panchthar and Udaypur, eastern districts of Nepal (Fig. 1). The Tamor River originates from the Kanchenjunga range and is a perennial glacial-fed river (Negi, 1991; Shrestha et al., 2009). The Kamala River originates from the Chure Hills and is a rain/spring-fed river with minimal flow during dry seasons. The Mewa, the Maiwa and the Hewa are the Tamor's tributaries whereas the Tawa is a tributary of the Kamala and the Lalleri is a tributary of the Tawa (Fig. 1; Table 1). The Mewa Khola (Khola in Nepali means stream) originates in Sudu Pokhari at an elevation of 3800 masl and it confluences with the Tamor River at Dobhan (Shrestha et al., 2016).
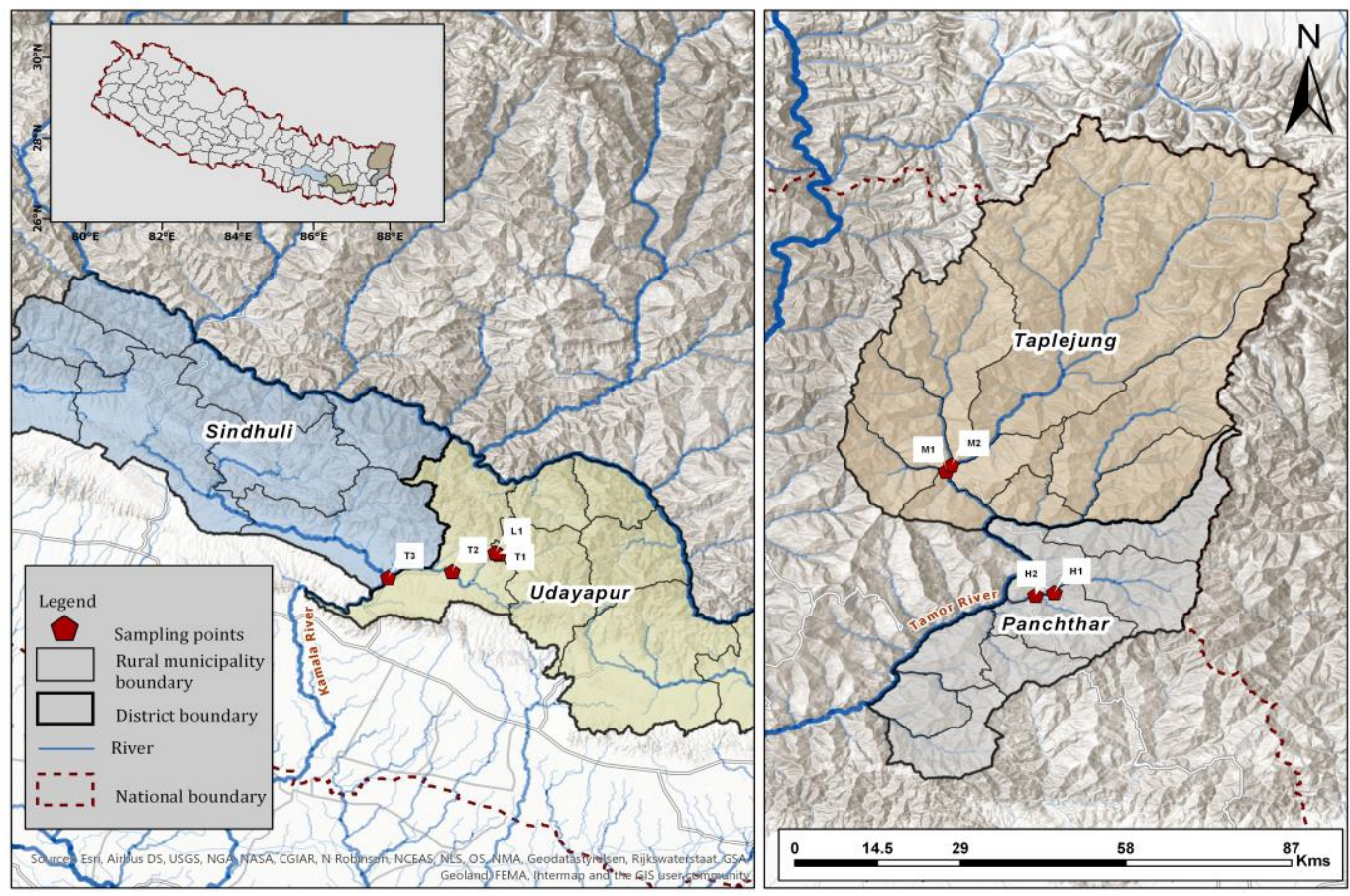

Figure 1 Map of Nepal showing the study area's location (in the inset) and the sampling sites.

\section{Macroinvertebrate collection}

A seasonal approach of sampling was adopted encompassing four seasons - March 2015 (Spring), November 2015 (Autumn), January 2016 (Winter), and May 2016 (Summer). Sites were chosen based on accessibility and proximity to the confluence in the case of the Tamor (Jha et al., 2018). Macroinvertebrates were sampled from around a hundred-meter river stretch with a hand net of mesh size $250 \mu \mathrm{m}$ following Barbour et al. (1999). This method involves the inclusion of different microhabitats such as the riffles, pools, runs, and different substratum types. The collected organisms were preserved in $70 \%$ ethanol in the field itself and samples were transferred to the laboratory for identification to Family level following standard literature (Merritt \& Cummins, 1996; Nesemann et al., 2007). Selected water parameters viz. dissolved oxygen (DO), conductivity, temperature and $\mathrm{pH}$ were measured on-site using portable multi-parameter probe (LUTRON).

\section{Data analysis}

Percentage abundance of the different Orders of macroinvertebrates was calculated. Percentage EPT richness was also calculated for its comparison with the other Orders using the following formula:

$\% \mathrm{EPT}=$ Number of Families belonging to

Orders Ephemeroptera, Plecoptera and Trichoptera /Total number of Families found $* 100$ 
Table 1 Sampling sites, geographical coordinates, dominant substratum types, surrounding land-use and river stressors. Modified from Jha et al. (2015; 2018).

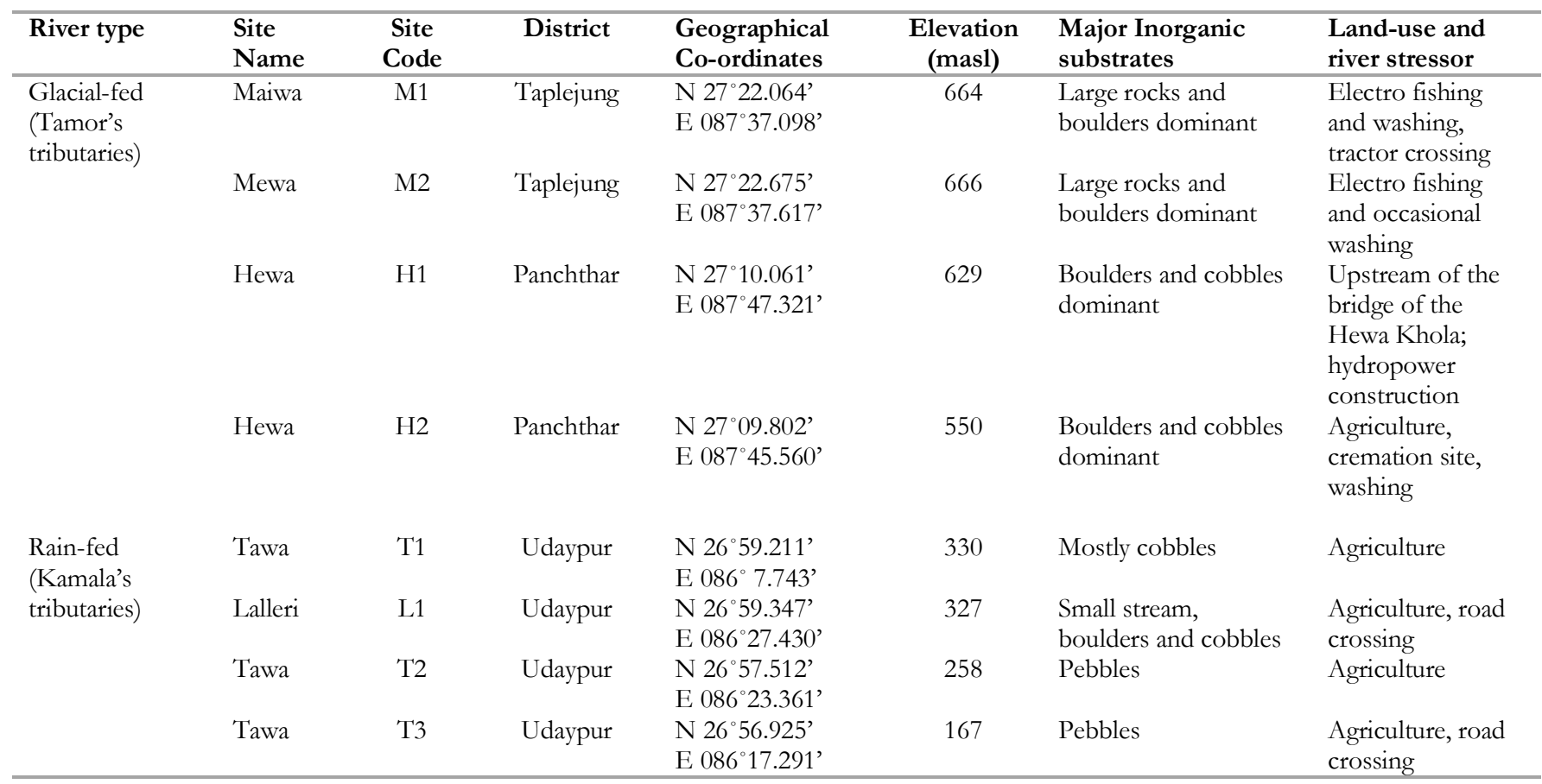

Shannon-Wiener diversity index (up to Family level) was estimated following Magurran (2004). Non-Metric Multidimensional Scaling (NMDS) was performed using R-programming to assess site-wise similarity of macroinvertebrate assemblages. ANOSIM (Analysis of similarity) was performed to assess significant variation in assemblages between the Tamor and the Kamala systems. Spearman rank correlation coefficient was used to assess the correlation between \% EPT, Shannon-Wiener diversity index (Family-based) and physico-chemical variables. T-test was conducted to assess significant differences in \% EPT, Shannon-Wiener diversity index, and Family richness between river systems.

\section{Results and Discussion}

Macroinvertebrate assemblages

A total of 49 Families belonging to 15 Orders and 5 Classes of macroinvertebrates were identified from the two selected river systems (Fig. 2; Table 2) indicating a rich macroinvertebrate fauna.

Studies conducted by Füreder et al. (1998) and Shah et al. (2020b) found that the spring-fed systems had a greater number of macroinvertebrate Families. However, our study found more in the glacial-fed system. Pokharel (2013) found similar results where the glacial-fed system had a greater taxonomic richness due to less urban influence in such systems. This may be the case in our study as well. Although a number of Families were common to both rivers, some Families were observed exclusively in either the glacial-fed Tamor system or the rain-fed Kamala system. NMDS revealed two distinct assemblages for the glacial-fed and rain-fed tributaries (Fig. 3). ANOSIM revealed significant variation in assemblages between the Tamor and the Kamala systems $(\mathrm{R}=0.79 ; \mathrm{p}<0.05)$.

Families Nemouridae, Rhyacophilidae and Stenopsychidae were found exclusively in the tributaries of the glacial-fed Tamor system. Nemouridae and Rhyacophilidae are typical of snow-fed and glacial-fed lotic systems and are well adapted to cold water mountain streams (Hilsenhoff, 2001; Hotaling et al., 2020; Saito et al., 2018) and have previously been reported from cold fast-flowing rivers and streams from Nepal as well (Sharma, 1996). In contrast, Naididae, Nepidae and Thiaridae were among the Families found exclusively in the tributaries of the Kamala. The presence of these taxa has been reported in warm lowland waters in Nepal by Nesemann (2006) and Khatri et al. (unpublished data) as well. These taxa are known to be pollution tolerant (Dodds \& Whiles, 2010; Silva et al., 2010) and their presence points to human disturbances such as agricultural runoff, fish poisoning, cremation, washing and cattle farming (Thapa, 2015). A study by Akindele and Liadi (2014) have reported correlation of these taxa with nitrate in a tropical Nigerian stream as well. Agriculture was the most dominant landuse in the sampling sites at Tawa and Lalleri. These reasons coupled with lesser dissolved oxygen probably explain the presence of these organic pollution tolerant taxa in the Kamala system. 
Table 2 Macroinvertebrate taxa observed in sampling sites

\begin{tabular}{|c|c|c|c|c|c|c|c|c|c|}
\hline \multicolumn{2}{|c|}{ Macroinvertebrate taxa } & \multicolumn{8}{|c|}{ Sites } \\
\hline Order/Taxa & Family & M1 & M2 & $\mathrm{H} 1$ & $\mathrm{H} 2$ & $\mathrm{~T} 1$ & L1 & $\mathrm{T} 2$ & T3 \\
\hline \multirow[t]{2}{*}{ Plecoptera } & Perlidae & ++ & ++ & ++ & ++ & ++ & ++ & ++ & ++ \\
\hline & Nemouridae & -- & ++ & -- & -- & -- & -- & -- & -- \\
\hline \multirow{6}{*}{ Ephemeroptera } & Baetidae & ++ & ++ & ++ & ++ & ++ & ++ & ++ & ++ \\
\hline & Caenidae & ++ & -- & ++ & ++ & -- & -- & ++ & ++ \\
\hline & Ephemerellidae & ++ & ++ & ++ & ++ & ++ & ++ & ++ & ++ \\
\hline & Ephemeridae & ++ & ++ & -- & -- & ++ & -- & -- & -- \\
\hline & Heptageniidae & ++ & ++ & ++ & ++ & ++ & ++ & -- & ++ \\
\hline & Leptophlebiidae & -- & -- & -- & ++ & ++ & ++ & ++ & ++ \\
\hline \multirow[t]{10}{*}{ Trichoptera } & Hydropsychidae & ++ & ++ & ++ & ++ & ++ & ++ & ++ & ++ \\
\hline & Glossosomatidae & ++ & ++ & ++ & -- & -- & -- & -- & -- \\
\hline & Philopotamidae & ++ & ++ & -- & -- & ++ & ++ & -- & -- \\
\hline & Stenopsychidae & ++ & -- & ++ & -- & -- & -- & -- & -- \\
\hline & Brachycentridae & -- & ++ & -- & -- & -- & -- & -- & -- \\
\hline & Limnocentropodidae & -- & ++ & -- & -- & -- & -- & -- & -- \\
\hline & Psychomyiidae & -- & ++ & -- & -- & -- & -- & -- & -- \\
\hline & Rhyacophilidae & -- & ++ & -- & -- & -- & -- & -- & -- \\
\hline & Uenoidae & -- & ++ & ++ & -- & -- & -- & -- & -- \\
\hline & Trichoptera in. det. & -- & ++ & ++ & -- & -- & -- & -- & -- \\
\hline \multirow[t]{9}{*}{ Diptera } & Blephariceridae & ++ & -- & ++ & ++ & -- & -- & -- & -- \\
\hline & Simuliidae & ++ & ++ & ++ & ++ & ++ & ++ & ++ & -- \\
\hline & Tabanidae & ++ & -- & -- & -- & ++ & ++ & ++ & ++ \\
\hline & Limoniidae & -- & ++ & ++ & ++ & ++ & ++ & ++ & ++ \\
\hline & Tipulidae & -- & ++ & ++ & -- & -- & -- & -- & -- \\
\hline & Chironomidae & -- & ++ & ++ & ++ & ++ & ++ & ++ & ++ \\
\hline & Ceratopogonidae & -- & -- & -- & -- & -- & -- & ++ & -- \\
\hline & Dolichopodidae & -- & -- & -- & ++ & ++ & ++ & -- & -- \\
\hline & Diptera in. det. & -- & -- & ++ & -- & -- & -- & -- & -- \\
\hline \multirow[t]{4}{*}{ Odonata } & Gomphidae & ++ & ++ & ++ & ++ & ++ & ++ & ++ & ++ \\
\hline & Euphaeidae & -- & ++ & ++ & -- & -- & -- & -- & -- \\
\hline & Coenagrionidae & -- & -- & ++ & -- & -- & -- & -- & -- \\
\hline & Corduliidae & -- & -- & -- & -- & ++ & -- & -- & -- \\
\hline \multirow[t]{5}{*}{ Hemiptera } & Aphelocheiridae & ++ & -- & ++ & -- & -- & -- & -- & ++ \\
\hline & Naucoridae & -- & ++ & -- & -- & -- & -- & -- & -- \\
\hline & Gerridae & -- & -- & ++ & ++ & ++ & ++ & -- & -- \\
\hline & Nepidae & -- & -- & -- & -- & ++ & ++ & -- & ++ \\
\hline & Micronectidae & -- & -- & -- & -- & -- & -- & ++ & -- \\
\hline \multirow[t]{3}{*}{ Coleoptera } & Gyrinidae & -- & ++ & ++ & ++ & ++ & -- & -- & ++ \\
\hline & Elmidae & -- & ++ & ++ & ++ & -- & -- & ++ & ++ \\
\hline & Psephenidae & -- & -- & -- & ++ & ++ & -- & ++ & -- \\
\hline Megaloptera & Corydalidae & -- & ++ & -- & ++ & ++ & ++ & ++ & -- \\
\hline Decapoda $^{1}$ & Potamidae & -- & -- & ++ & ++ & ++ & ++ & -- & -- \\
\hline Crustacea $^{1 \#}$ & Palaemonidae & -- & -- & -- & -- & ++ & ++ & ++ & ++ \\
\hline \multirow[t]{3}{*}{ Oligochaeta ${ }^{1 \dagger}$} & Hirudinidae & ++ & -- & ++ & -- & -- & -- & -- & -- \\
\hline & Oligochaeta in. det. & -- & -- & ++ & -- & -- & -- & -- & -- \\
\hline & Naididae & -- & -- & ++ & -- & -- & -- & ++ & -- \\
\hline \multirow[t]{4}{*}{ Mollusca ${ }^{1 *}$} & Planorbidae & -- & -- & -- & -- & -- & -- & -- & ++ \\
\hline & Lymnaeidae & -- & -- & -- & -- & ++ & & ++ & -- \\
\hline & Thiaridae & -- & -- & -- & -- & ++ & ++ & -- & -- \\
\hline & Viviparidae & -- & -- & -- & -- & -- & -- & -- & -- \\
\hline
\end{tabular}

Note:1 means non-insect fauna; \# means Class; † means Subclass; * means Phylum; ++ means present; -- means absent 


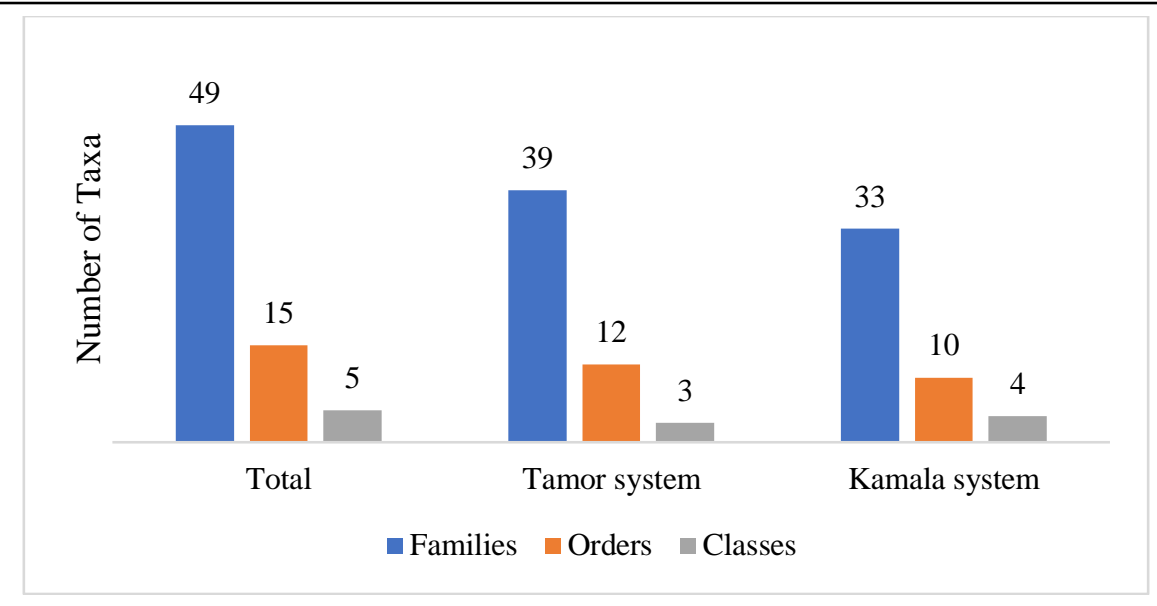

Figure 2 Total number of Families, Orders and Classes observed in the Tamor and Kamala systems.

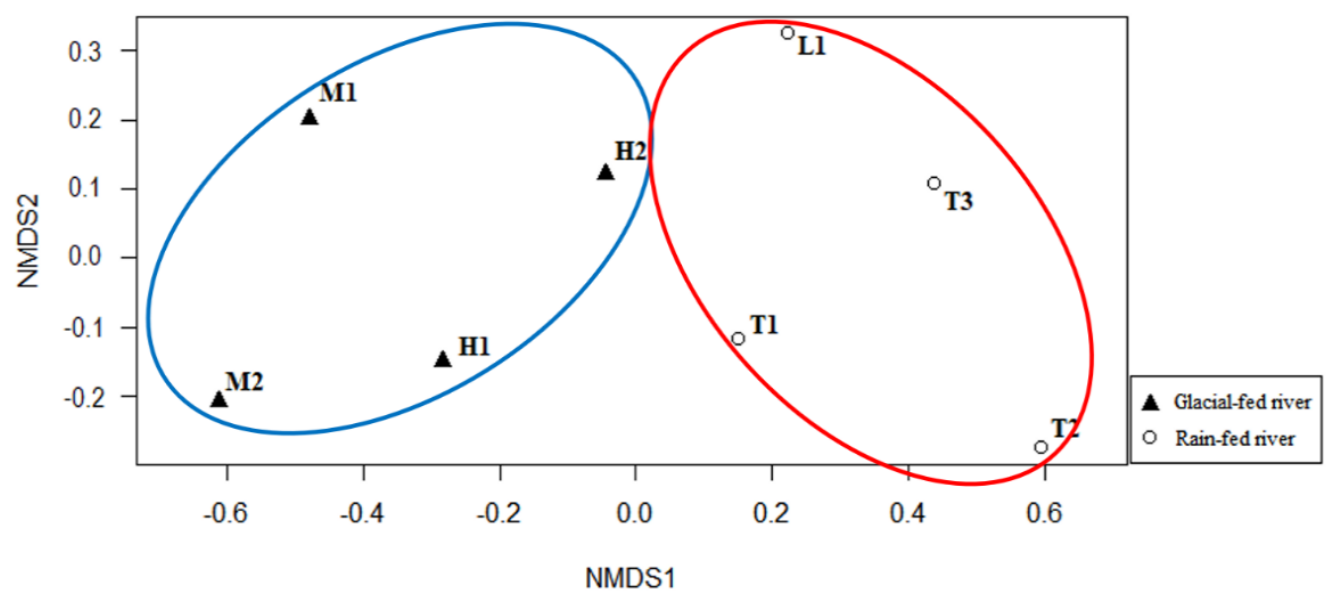

Figure 3 NMDS graph showing glacial-fed and rain-fed sites with two clusters

Figures $4 \mathrm{a}$ and $4 \mathrm{~b}$ show the percentage composition of different macroinvertebrate Orders observed in the tributaries of the Tamor and the Kamala. The most dominant Order in Tamor's tributaries was Ephemeroptera, followed by Trichoptera and Diptera. In rain-fed systems, the Order Trichoptera was the most dominant, followed by Ephemeroptera, Diptera, and Odonata. The abundance of Plecoptera - a cold water taxon (Bouchard, 2004; Cui et al., 2019), was higher in the glacial-fed river. Similar findings were observed in the Patagonian Andean glacial streams and the Austrian Central Alps (Füreder et al., 1998; Martyniuk et al., 2019). The most dominant Family in the Tamor was Baetidae. This taxon is quite common in streams and the abundance of this Family has been reported in other glacial streams (Milner et al., 2001; Mishra et al., 2013) as well as in nutrient-rich streams (Harrington \& Born, 2000). The Trichoptera Family Hydropsychidae is a cosmopolitan taxon commonly found in a range of lotic systems (Oliveira \& Froehlich, 1996). This taxon represents one of the major insect groups in Southeast Asia (Uy et al., 2018) and has been reported from a large number of lotic systems across Nepal (Ormerod et al., 1994; Pokharel,
2013). This taxon was the most dominant Family in Kamala's tributaries. Jha et al. (2015) also reported abundant Hydropsychidae in the Kamala systems. This taxon is also referred to as net spinners and are filter feeders trapping fine particulate organic matter from running waters (Dudgeon, 1999). Their abundance in lowland Tawa is an indication of presence of suspended sediment and fine particulate organic matter in water.

The percentage of EPT (Ephemeroptera, Plecoptera and Trichoptera) was higher in Tamor's tributaries (Fig. 5). Ttest further revealed that the observed sample means of $\%$ EPT differed significantly for the Tamor and Kamala $\operatorname{river}(\mathrm{t}(6)=-5.9, \mathrm{p}=0.001)$.

Rundle et al. (1993), Ormerod et al. (1994), and Suren (1994) found EPT to be the abundant Orders in their studies from different lotic systems in Nepal. In this study also, EPT abundance was found to be greater than those of other Orders in both rivers in all the seasons (Figs. 6a and $6 \mathrm{~b})$. The overall EPT abundance in the glacial-fed river was $79 \%$, whereas for the rain-fed river, it was $61 \%$. 

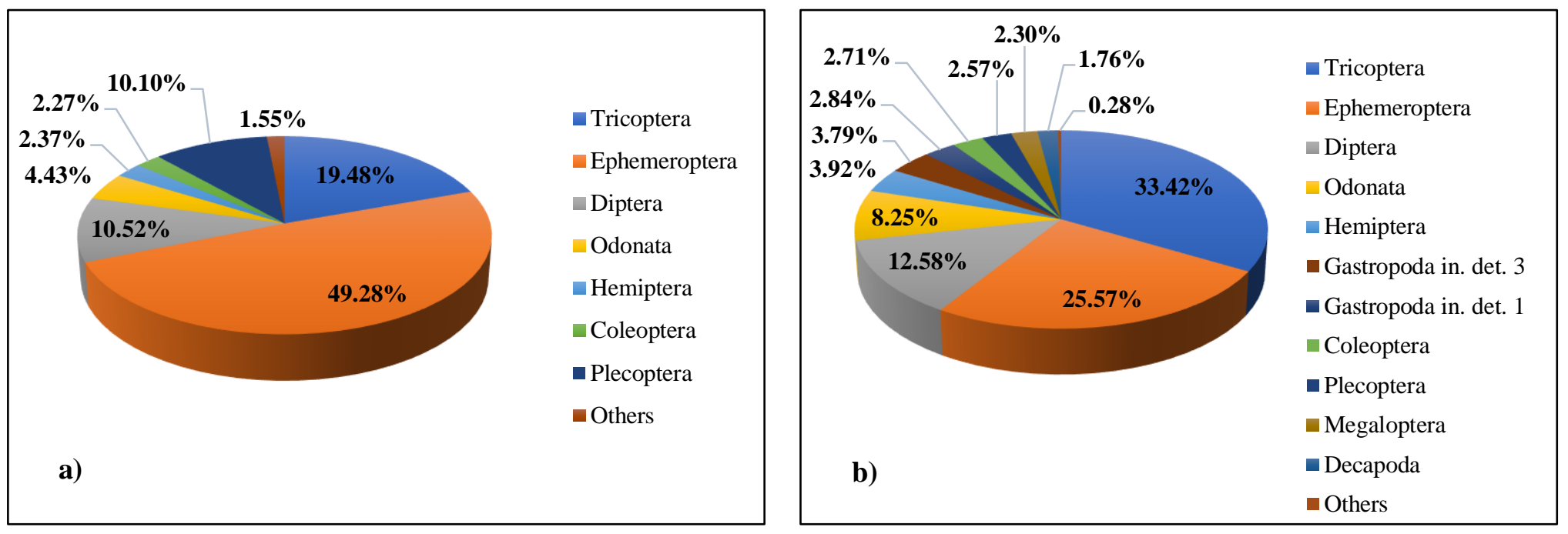

Figure 4 Percentage abundance of different macroinvertebrate Orders in (a) Tamor system and (b) Kamala system

Most of the EPT taxa are considered to be pollution sensitive and the \% EPT is regarded as a simple and crude indicator of environmental water quality (Feld et al., 2010). Higher $\%$ EPT values in all seasons in sites M1, M2, H1 and H2 indicates better water quality in Tamor's tributaries. This finding is supported by the fact that Tamor's tributaries have higher levels of dissolved oxygen (Jha et al., 2018), fast-flowing waters, and less organic pollution. In contrast, although the overall proportion of \% EPT was higher in all of the Kamala's tributaries, contributions from other Orders were also significant, most possibly reflecting agricultural runoff in the area.

\section{Macroinvertebrate assemblages and seasonal variation}

Figures $6 \mathrm{a}$ and $6 \mathrm{~b}$ show the percentage abundance of EPT and other taxa in different seasons in the tributaries of the Tamor and Kamala respectively. The EPT dominated in all the seasons in both the systems. In the Tamor's tributaries, EPT was dominant throughout the seasons, and it was highest during the autumn. The highest EPT abundance in Kamala's tributaries was observed during the winter, but other taxa also showed significant contribution during other seasons.
Seasonal variation in macroinvertebrate assemblages have been reported by several authors (Brewin et al., 2000; Mesa, 2012). Seasons tend to affect a range of environmental variables, such as water temperature, discharge and habitat changes which in turn influence community characteristics like food availability (Mesa, 2012; Miserendino \& Pizzolon, 2003). For instance, it has been shown that higher discharge during the wet season tend to dilute pollution and improve the quality of macroinvertebrate assemblages (Jacobsen, 1998; Jacobsen \& Encalada 1998). Furthermore, seasons also affect the emergence time of macroinvertebrates (Baxter et al., 2017; Milner \& Petts, 1994). Sweeney and Vannote (1982) and Malison and Baxter (2010) found that emergence was greatest during the summer season.

\section{Macroinvertebrate assemblages and physico-chemical parameters}

Table 3 shows the mean values of selected physico-chemical parameters and Tables $4 \mathrm{a}$ and $4 \mathrm{~b}$ show the Spearman rank correlation of macroinvertebrate assemblages with physicochemical parameters. All the sites were characterized by circum-neutral to slightly alkaline $\mathrm{pH}$. As expected, rain-fed Kamala's tributaries had higher temperature than those of glacial-fed Tamor's tributaries. Conductivity was also higher in Kamala's tributaries (Table 3). 


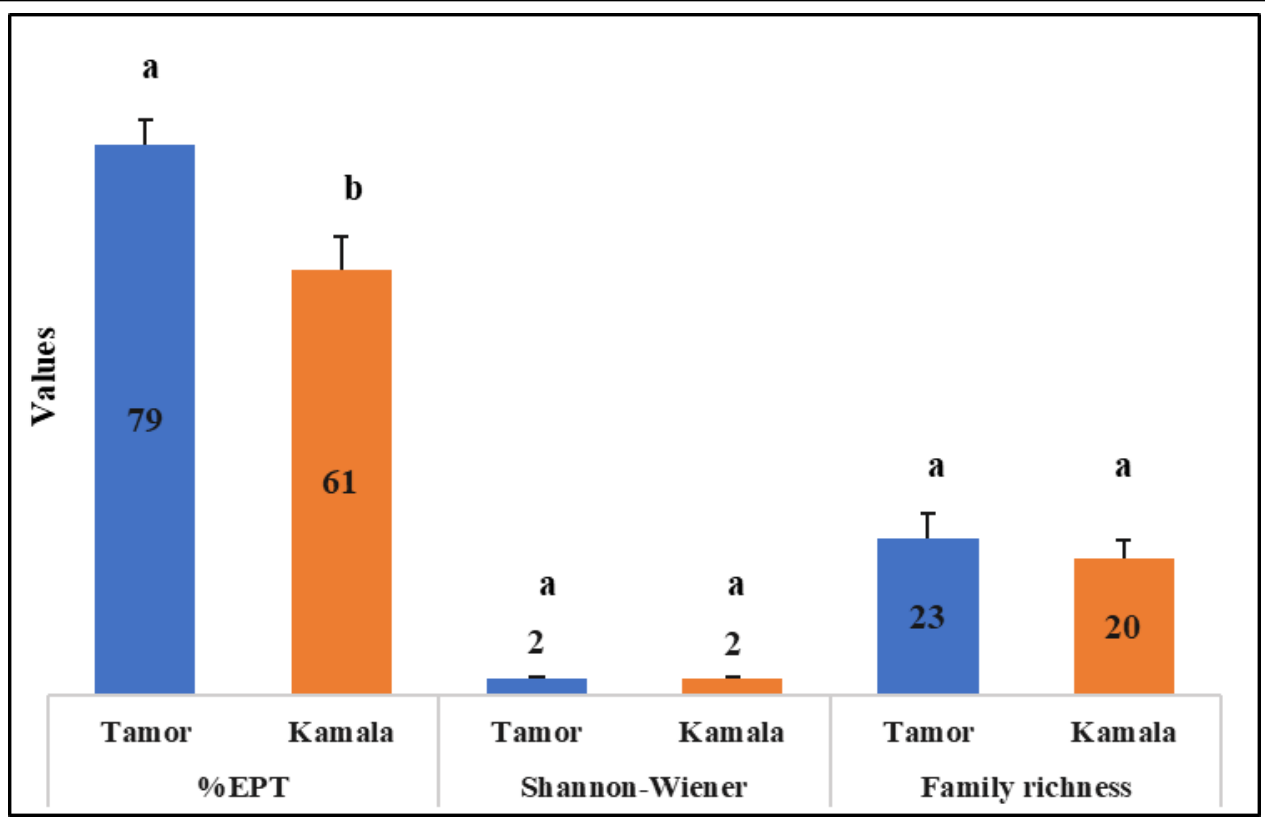

Figure $5 \% \mathrm{EPT}$, Shannon-Wiener, Family richness difference between the headwater tributaries of the glacial-fed Tamor system and the rain-fed Kamala system. [Error bars with different letters denote significant difference $(T$-test; $\mathrm{p}<0.05)$ ].

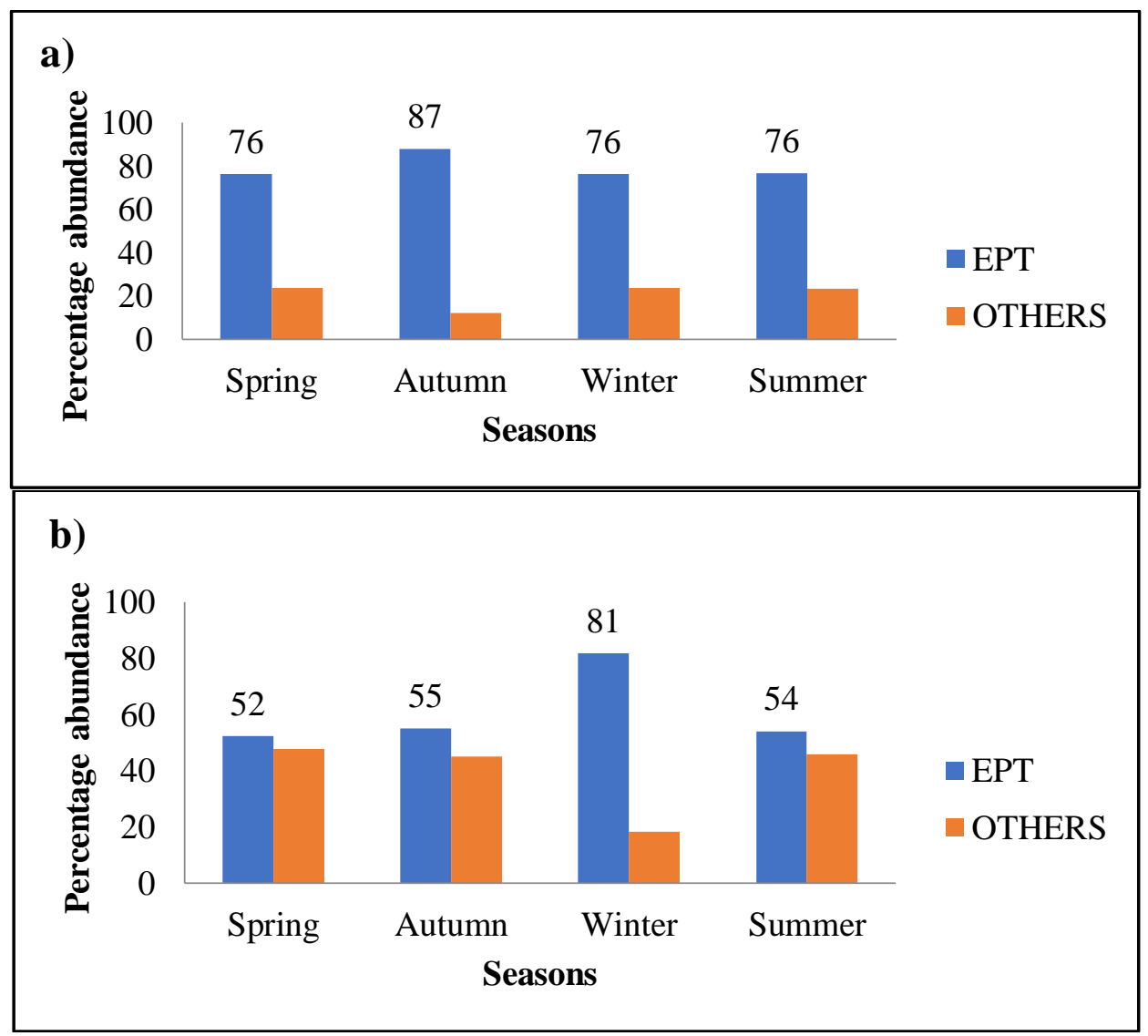

Figure 6 Seasonal comparison of EPT and other Orders (a) Tamor system (b) Kamala system 
Table 3 Physico-chemical parameters of the sampling sites

\begin{tabular}{|c|c|c|c|c|c|}
\hline \multirow[t]{2}{*}{ River type } & \multirow[t]{2}{*}{ Site } & \multicolumn{4}{|c|}{ Parameters } \\
\hline & & $\mathrm{pH}$ & $\begin{array}{c}\text { Temperature } \\
\left({ }^{\circ} \mathrm{C}\right)\end{array}$ & $\begin{array}{c}\text { Dissolved oxygen } \\
\left(\mathrm{mgL}^{-1}\right)\end{array}$ & $\begin{array}{l}\text { Conductivity } \\
\left(\mu \mathrm{Scm}^{-1}\right)\end{array}$ \\
\hline Glacial-fed & M1 & $7.07 \pm 0.46$ & $16.41 \pm 3.07$ & $6.62 \pm 1.90$ & $57.98 \pm 7.40$ \\
\hline (Tamor's & M2 & $7.47 \pm 0.38$ & $14.24 \pm 2.66$ & $7.38 \pm 2.46$ & $48.10 \pm 6.48$ \\
\hline \multirow[t]{3}{*}{ tributaries) } & H1 & $7.23 \pm 0.16$ & $17.28 \pm 5.50$ & $6.29 \pm 1.65$ & $50.26 \pm 11.22$ \\
\hline & $\mathrm{H} 2$ & $7.51 \pm 0.26$ & $16.73 \pm 3.49$ & $6.30 \pm 2.49$ & $62.63 \pm 6.05$ \\
\hline & Average & $7.32 \pm 0.37$ & $16.17 \pm 3.89$ & $6.65 \pm 2.11$ & $54.74 \pm 9.78$ \\
\hline Rain-fed & T1 & $7.99 \pm 0.53$ & $23.89 \pm 3.72$ & $6.03 \pm 1.70$ & $241.15 \pm 58.14$ \\
\hline (Kamala's & L1 & $8.12 \pm 0.63$ & $24.95 \pm 4.94$ & $5.45 \pm 2.57$ & $283.52 \pm 26.24$ \\
\hline \multirow[t]{3}{*}{ tributaries) } & $\mathrm{T} 2$ & $8.22 \pm 0.54$ & $25.18 \pm 6.20$ & $5.41 \pm 2.04$ & $286.50 \pm 43.03$ \\
\hline & T3 & $7.62 \pm 0.92$ & $24.02 \pm 6.86$ & $5.46 \pm 3.36$ & $354.18 \pm 29.73$ \\
\hline & Average & $7.99 \pm 0.69$ & $24.51 \pm 5.41$ & $5.60 \pm 2.40$ & $293.83 \pm 60.10$ \\
\hline
\end{tabular}

Source: Jha et al. (2018)

Table 4a Spearman rank's correlation coefficient for physico-chemical parameters and macroinvertebrate assemblages attributes in Tamor's tributaries

\begin{tabular}{|c|c|c|c|c|c|c|c|}
\hline & $\mathrm{pH}$ & Temperature & DO & Conductivity & $\begin{array}{c}\text { Taxa } \\
\text { Richness }\end{array}$ & $\%$ EPT & $\begin{array}{c}\text { Shannon } \\
\text { Diversity }\left(\mathrm{H}^{\prime}\right)\end{array}$ \\
\hline $\mathrm{pH}$ & 1 & & & & & & \\
\hline Temperature & 0.325 & 1 & & & & & \\
\hline DO & $.662^{*}$ & 0.294 & 1 & & & & \\
\hline Conductivity & 0.364 & 0.465 & $.643^{*}$ & 1 & & & \\
\hline Taxa Richness & 0.188 & $-.507^{*}$ & 0.014 & -0.142 & 1 & & \\
\hline \% ЕPT & -0.036 & $-.651^{* *}$ & 0.257 & -0.085 & $.762^{* *}$ & 1 & \\
\hline $\begin{array}{l}\text { Shannon } \\
\text { Diversity (H') }\end{array}$ & 0.050 & -0.302 & 0.021 & -0.129 & $.870^{* *}$ & $.647^{* *}$ & 1 \\
\hline
\end{tabular}

Table 4b Spearman rank's correlation coefficient for physico-chemical parameters and macroinvertebrate assemblages attributes in Kamala's tributaries

\begin{tabular}{|c|c|c|c|c|c|c|c|}
\hline & $\mathrm{pH}$ & Temperature & DO & Conductivity & $\begin{array}{c}\text { Taxa } \\
\text { Richness }\end{array}$ & $\%$ EPT & $\begin{array}{c}\text { Shannon } \\
\text { Diversity }\left(\mathrm{H}^{\prime}\right)\end{array}$ \\
\hline $\mathrm{pH}$ & 1 & & & & & & \\
\hline Temperature & -0.168 & 1 & & & & & \\
\hline DO & -0.455 & 0.294 & 1 & & & & \\
\hline Conductivity & -0.385 & 0.394 & 0.203 & 1 & & & \\
\hline Taxa Richness & -0.129 & -0.138 & -0.169 & -0.067 & 1 & & \\
\hline \% EPT taxa & -0.101 & -0.096 & -0.431 & -0.099 & $.734^{* *}$ & 1 & \\
\hline $\begin{array}{l}\text { Shannon } \\
\text { Diversity (H') }\end{array}$ & -0.253 & 0.371 & 0.287 & 0.335 & $.650^{* *}$ & 0.203 & 1 \\
\hline
\end{tabular}

In both the river systems, \% EPT and Shannon Wiener diversity showed positive correlation $(\mathrm{p}<0.01)$ with taxa richness. In Tamor's tributaries, taxa richness and \% EPT showed significant negative correlation $(p<0.01)$ whereas in Kamala's tributaries although these parameters showed negative correlation, significant variations were not observed. Temperature and oxygen are crucial parameters in shaping up macroinvertebrate communities in many aquatic systems (Fumetti et al., 2017; Jacobsen, 2008) along with substrate types, hydrological regimes (Beauger et al., 2006). Being ectotherms, for most macroinvertebrate assemblages, an increase in temperature may lead to their decline (Durance \& Ormerod, 2007; Woodward et al., 2010). Tamiru et al. (2017) found that low dissolved oxygen levels caused disease and slow growth rates, resulting in a drop in the percentage of EPT. Studies have found that macroinvertebrate abundance and richness decreased with a decrease in $\mathrm{pH}$ (Baldigo et al., 2009; Duggan et al., 2007; Gaskill, 2014) particularly the Ephemeroptera (Courtney \& Clements, 1998). 


\section{Conclusion}

This study was conducted to generate baseline information on macroinvertebrate assemblages of the glacial-fed Tamor's and rain-fed Kamala's tributaries in eastern Nepal. A total of 49 macroinvertebrate Families were observed indicating rich macroinvertebrate diversity. The macroinvertebrate assemblages differed in the two systems. The most dominant Order was Ephemeroptera and Trichoptera in the Tamor's tributaries and Kamala's tributaries respectively. Certain taxa like Rhyacophilidae and Stenopsychidae were observed exclusively in glacialfed Tamor's tributaries whereas warm water taxa were characteristics of rain-fed systems, clearly reflecting a difference in the abiotic variables attributed to glacial-fed and rain-fed catchments. The presence of taxa like Naididae and Thiaridae were observed in Kamala's tributaries and indicate organic pollution in the rivers. This baseline data can serve as the foundation for further bioassessment including climate change impacts on aquatic biodiversity.

Acknowledgements: This work was supported by National Academy of Science and Technology (NAST) and Asian Development Bank (ADB). We thank Tenzing Chogyal Sherpa for preparing the map of the study area. Shekhar Acharya, Anuja Thapa, Mamta KC, Bikash Gurung are acknowledged for their help in the field. We thank the anonymous reviewers for their constructive comments and suggestions.

Author Contributions: SG: Conceptualization, sampling, analysis, manuscript preparation; RS and BW: manuscript preparation and statistical analyses; BRJ: Logistics and sampling; KK: Sampling; DJ: MS revision.

Conflict of Interest: The authors declare no conflict of interest.

Data Availability Statement: The data that support the findings of this study are available from the corresponding author, upon reasonable request.

\section{References}

Akindele, E.O., \& Liadi, A.A. (2014). Diversity and response of benthic macroinvertebrates to natural and induced environmental stresses in Aiba Stream, Iwo, south-western Nigeria. West African Journal of Applied Ecology, 22(1), 101-111.

Beauger, A., Lair, N., Reyes-Marchant, P., \& Peiry, J.L. (2006). The distribution of macroinvertebrate assemblages in a reach of the River Allier (France), in relation to riverbed characteristics. Hydrobiologia, 571(1), 63-76. doi 10.1007/s107 50-006-0217-x.

Baldigo, B.P., Lawrence, G.B., Bode, R.W., Simonin, H. A., Roy, K.M., \& Smith, A.J. (2009). Impacts of acidification on macroinvertebrate communities in streams of the western Adirondack Mountains, New York, USA. Ecological Indicators, 9(2), 226-239. doi 10.1016/j.ecolind.2008.04.004.

Barbour, M.T., Gerritsen, J., Snyder, B.D., \& Stribling, J. B. (1999). Rapid Bioassessment Protocols for use in streams and wadeable rivers: Periphyton, Benthic Macroinvertebrates, and Fish. USEPA.

Baxter, C.V., Kennedy, T.A., Miller, S.W., Muehlbauer, J. D., \& Smock, L.A. (2017). Macroinvertebrate drift, adult insect emergence and oviposition. In F.R. Hauer, \& G.A. Lamberti
(Eds.), Methods in Stream Ecology, Volume 1 (Third Edition). Academic Press, pp. 435-456.

Bouchard, R.W. (2004). Guide to aquatic macroinvertebrates of the Upper Midwest. Water Resources Center, University of Minnesota, St. Paul, MN.

Brewin, P.A., Buckton, S.T., \& Ormerod, S.J. (2000). The seasonal dynamics and persistence of stream macroinvertebrates in Nepal: Do monsoon floods represent disturbance? Freshwater Biology, 44(4), 581-594. doi 10.1046/j .1365-2427.2000.00608.x.

Buss, D.F., Baptista, F., Silveira, M.P., Nessimian, J.L., \& Dorvill, F.M. (2002). Influence of water chemistry and environmental assemblages in a river basin in south-east Brazil. Hydrobiologia, $81,125-13$

Courtney, L.A., \& Clements, W.H. (1998). Effects of acidic pH on benthic macroinvertebrate communities in stream microcosms. Hydrobiologia, 379, 135-145.

Cui, Y., Shih, C., \& Ren, D. (2019). Plecoptera - Stoneflies. In D. Ren, C.K. Shih, T. Gao, Y. Yao, \& Y. Wang (Eds.), Rhythms of Insect Evolution: Evidence from Jurassic and Cretaceous in northern China. John Wiley \& Sons, pp. 175-184.

Cummins, K.W. (1974). Structure and function of stream ecosystems. BioScience, 24(11), 631-641. doi 10.2307/1296676

Dodds, W.K., \& Whiles, M.R. (2010). Multicellular Animals. In W.K. Dodds, \& M.R. Whiles (Eds.), Freshwater Ecology. Academic Press, pp. 221-257.

Dudgeon, D. (1999). Tropical Asian Streams: Zoobenthos, Ecology and Conservation. Hong Kong Press.

Duggan, I.C., Boothroyd, I.K.G., \& Speirs, D.A. (2007). Factors affecting the distribution of stream macroinvertebrates in geothermal areas: Taupo volcanic zone, New Zealand. Hydrobiologia, 592, 235-247.

Durance, I., \& Ormerod, S.J. (2007). Climate change effects on upland stream macroinvertebrates over a 25 -year period. Global Change Biology, 13(5), 942-957. doi 10.1111/j.13652486.2007.01340.x.

Espinosa, R., Andino, P., Cauvy-Fraunié, S., Dangles, O., Jacobsen, D., \& Crespo-Pérez, V. (2020). Diversity patterns of aquatic macroinvertebrates across stream types and glacial influence in a tropical high-Andean catchment. Biología Tropical, 68, 39-53.

Eriksen, T.E., Brittain J.E., Søli, G., Jacobsen, D., Goethalsf, P., \& Friberg, N. (2021). A global perspective on the application of riverine macroinvertebrates as biological indicators in Africa, South-Central America, Mexico and Southern Asia. Ecological Indicators, 126, 107609. doi 10.1016/j.ecolind.2021.1 07609

Feld, C.K., Tangelder, M., Klomp, M.J., \& Sharma, S. (2010). Comparison of river quality indices to detect the impact of organic pollution and water abstraction in Hindu KushHimalayan rivers of Nepal. Journal of Wetlands Ecology, 4, 112117.

Fumetti, S., Bieri-Wigger, F., \& Nagel, P. (2017). Temperature variability and its influence on macroinvertebrate assemblages of alpine springs. Ecobydrology, 10(7), 1-9.

Füreder, L., Schütz, C., Burger, R., \& Walinger, M. (1998). High Alpine streams as models for ecological gradients. LAHS Publication, 248, 387-394.

Gaskill, J.A. (2014). Examining the effects of $p H$ and macrophyte diversity on benthic macroinvertebrate assemblages in Adirondack Lakes. (Honor Theses), SUNY College of Environmental Science and Forestry.

Gurung, S., Sharma, P., KC, M., Ulak, P., \& Sharma, S. (2013). Study of impact of stressors on water quality using macroinvertebrates as bioindicators in Andhi Khola, Nepal. In M.K. Balla, S. Rayamajhi, \& A. Singh (Eds.), Proceedings of the International Conference on Forests, People and Climate: Changing Paradigm. Pokhara, Nepal. 
Harrington, J., \& Born, M., (2000). Measuring the bealth of California streams and rivers - A Methods Manual for Water Resource Professional, Citizen Monitors and Natural Resources Student, Sacramento, California, USA. Second Edition. Sacramento, California, USA: Sustainable Land Stewardship International Institute, pp. 199.

Hauer, F.R., \& Resh, V.H. (2017). Macroinvertebrates. In F.R. Hauer, \& G.A. Lamberti (Eds.), Methods in Stream Ecology, Volume 1. Academic Press, pp. 297-319.

Heino, J. (2005). Functional biodiversity of macroinvertebrate assemblages along major ecological gradients of boreal headwater streams. Freshwater Biology, 50(9), 1578-1587. doi 10.1111/j.1365-2427.2005.01418.x.

Hilsenhoff, W.L. (2001). Diversity and classification of insects and collembola. In J. H. Thorp, \& A. P. Covich (Eds.), Ecology and Classification of North American Freshwater Invertebrates. (2nd Edition). Academic Press, pp. 661-731.

Hotaling, S., Shah, A., Dillon, M., Giersch, J., Tronstad, L., Finn, D., Woods, H., \& Kelly, J. (2020). Cold tolerance of mountain stoneflies (Plecoptera: Nemouridae) from the high Rocky Mountains. Western North American Naturalist, 81(1), 54-62. doi 10.3398/064.081.0105.

IUCN. (2016). Freshwater Biodiversity Assessments in the Eastern Himalaya Biodiversity Hotspot. IUCN. Retrieved October 20, 2020 from https://www.iucn.org/theme/specie s/our-work/freshwater-biodiversity/what-we-do/freshwater r-biodiversity-assessments-eastern-himalaya-biodiversity-hots pot.

Jacobsen, D. (1998). Influence of organic pollution on the macroinvertebrate fauna of Ecuadorian highland streams. Archiv für Hydrobiologie, 143, 179-195.

Jacobsen, D. (2008). Low oxygen pressure as a driving factor for the altitudinal decline in taxon richness of stream macroinvertebrates. Oecologia, 154(4),795-807.

Jacobsen, D. (2009). Classical alpine streams on the equator: are they different? Proceedings of the International Association of Theoretical and Applied Limnology, 30,1245-1250.

Jacobsen, D., \& Encalada, A. (1998). The macroinvertebrate fauna of Ecuadorian highland streams and the influence of wet and dry seasons. Archiv für Hydrobiologie, 142, 53-70.

Jha, B.R., Gurung, S., Khatri, K., Gurung, A., Thapa, A., Mamta, K.C., Gurung, B., \& Acharya, S. (2018). Patterns of diversity and conservation status of freshwater fishes in the glacial fed and rain fed rivers of Eastern Nepal. Environmental Biology of Fishes, 101(8), 1295-1305.

Jha, B.R., Gurung, S., Khatri, K., Gurung, B., Thapa, A., \& Acharya, S. (2015). River Ecological Study: Building The knowlegde base for variety of assessments such as climate change in Nepal. Journal of Mountain Area Research, 1, 28-39.

Korte, T., Baki, A.B.M., Ofenböck, T., Moog, O., Sharma, S., \& Hering, D. (2010). Assessing river ecological quality using benthic macroinvertebrates in the Hindu Kush-Himalayan region. Hydrobiologia, 651(1), 59-76.

Laursen, S.K., Hamerlik, L., Moltesen, K., Christoffersen, K.S., \& Jacobsen, D. (2015). Diversity and composition of macroinvertebrate assemblages in high-altitude Tibetan streams. Inland Waters, 5, 263-274.

LeCraw, R., \& Mackereth, R. (2010). Sources of small-scale variation in the invertebrate communities of headwater streams. Freshwater Biology, 55(6), 1219-1233.

Magurran, A.E. (2004). Measuring biological diversity. Blackwell Science Ltd.

Malison, R.L., \& Baxter, C.V. (2010). Effects of wildfire of varying severity on benthic stream insect assemblages and emergence. Journal of the North American Benthological Society, 29(4), 1324-1338.

Mantyka-Pringle, C.S., Martin, T.G., Moffatt, D.B., Linke, S., \& Rhodes, J.R. (2014). Understanding and predicting the combined effects of climate change and land-use change on freshwater macroinvertebrates and fish. Journal of Applied Ecology, 51(3), 572-581.

Martyniuk, N., Modenutti, B., \& Balseiro, E.G. (2019). Seasonal variability in glacial influence affects macroinvertebrate assemblages in North-Andean Patagonian glacier-fed streams. Inland $W$ aters, 9(4), 522-533.

Matangulu, M., Gurung, S., Prajapati, M., \& Jyakhwo, R. (2017). Macroinvertebrate assemblages as indicators of water quality of the West Seti River, Bajhang, Nepal. International Journal of Environment, 6(3), 25-45.

Merritt, R., \& Cummins, K.W. (1996). An introduction to the aquatic insects of North America. Kendall Hunt Publication.

Mesa, L.M. (2012). Interannual and seasonal variability of macroinvertebrates in monsoonal climate streams. Brazilian Archives of Biology and Technology, 55(3), 403-410.

Metcalfe, J.L. (1989). Biological water quality assessment of running waters based on macroinvertebrate communities: History and present status in Europe. Environmental Pollution, 60, 101-139.

Meyer, J.L., Strayer, D.L., Wallace, J.B., Eggert, S.L., Helfman, G.S., \& Leonard, N.E. (2007). The contribution of headwater streams to biodiversity in river networks. Journal of the American Water Resources Association, 43(1), 86-103.

Milner, A.M., \& Petts, G.E. (1994). Glacial rivers: Physical habitat and ecology. Freshwater Biology, 32(2), 295-307.

Milner, A.M., Brittain, J.E., Castella, E., \& Petts, G.E. (2001). Trends of macroinvertebrate community structure in glacierfed rivers in relation to environmental conditions: A synthesis. Freshwater Biology, 46(12), 1833-1847.

Miserendino, M.L., \& Pizzolon, L.A. (2003). Distribution of macroinvertebrate assemblages in the Azul-Quemquemtreu River basin, Patagonia, Argentina. New Zealand Journal of Marine and Freshwater Research, 37(3), 525-539.

Mishra, A., Nautiyal, P., \& Semwal, V.P. (2013). Distributional patterns of benthic macroinvertebrate fauna in the glacier fed rivers of Indian Himalaya. Our Nature, 11(1), 36-44.

Negi, S.S. (1991). Himalayan Rivers, Lakes, and Glaciers. New Delhi, India: Indus Publishing.

Nesemann, H.F. (2006). Macroinvertebrate non-insects' fauna and their role in biomonitoring of the Ganga River system. (MSc thesis), Kathmandu University, Nepal.

Nesemann, H., Sharma, S., Sharma, G., Khanal, S., Pradhan, B., Shah, D., \& Tachamo, R. (2007). Aquatic invertebrates of the Ganga River system. Aquatic Ecology Centre, Kathmandu University.

Ofenböck, T., Moog, O., Sharma, S., \& Korte, T. (2010). Development of the HKHbios: A new biotic score to assess the river quality in the Hindu Kush-Himalaya. Hydrobiologia, 651(1), 39-58. doi 10.1007/s10750-010-0289-5.

Oliveira, L.G., \& Froehlich, C.G. (1996). Natural history of three Hydropsychidae (Trichoptera, insecta) in a "cerrado" stream from northeastern São Paulo, Brazil. Revista Brasileira de Zoologia, 13(3), 755-762.

Ormerod, S.J., Rundle, S.D., Wilkinson, S.M., Daly, G.P., Dale, K.M., \& Jüttner, I. (1994). Altitudinal trends in the diatoms, bryophytes, macroinvertebrates and fish of a Nepalese river system. Freshwater Biology, 32(2), 309-322. doi 10.1111/j.13652427.1994.tb01128.x.

Patang, F., Soegianto, A., \& Hariyanto, S. (2018). Benthic macroinvertebrates diversity as bioindicator of water quality of some rivers in East Kalimantan. Indonesia. International Journal of Ecology, 5129421. doi 10.1155/2018/5129421.

Pokharel, K.K. (2013). Spatio-temporal variations of macroinvertebrates in riffles and pools of Mardi and Vijaypur Streams Pokhara, Nepal. Ecoprint: An International Journal of Ecology, 20, 61-70. doi 10.3126/eco.v20i0.11442. 
Poudel, K., Dahal, S., Dahal, B.M., \& Gurung, S. (2014). River water quality monitoring using benthic macroinvertebrates in Budhi and Singhiya River of Eastern Nepal. 289-299. In R.M. Bajracharya, B.K. Sitaula, S. Sharma and H.L. Shrestha (Eds.), Proceedings of International Conference on Forests, Soil and Rural Livelihoods in a Changing Environment. Kathmandu University.

Rice, S.P., Kiffney, P, Greene, C.M, \& Pess, G.R. (2008). The ecological importance of tributaries and confluences. In S.P. Rice, A.G. Roy, \& B.L. Rhoads (Eds.), River Confluences, Tributaries and the Fluvial Network. Wiley, Chichester, pp 209242.

Rundle, S.D., Jenkins, A., \& Ormerod, S.J. (1993). Macroinvertebrate communities in streams in the Himalaya, Nepal. Freshwater Biology, 30 (1), 169-180. doi 10.1111/j.13652427.1993.tb00797.x.

Saito, R., Kato, S., Kuranishi, R.B., Nozaki, T., Fujino, T., \& Tojo, K. (2018). Phylogeographic analyses of the Stenopsyche caddisflies (Trichoptera: Stenopsychidae) of the Asian Region. Freshwater Science, 37(3), 562-572. doi 10.1086/699364.

Shah, R.D.T., \& Shah, D.N. (2012). Performance of different biotic indices assessing the ecological status of rivers in the Central Himalaya. Ecological Indicators, 23, 447-452. doi 10.1016/j.ecolind.2012.04.001.

Shah, R.D.T., Sharma, S., \& Bharati, L. (2020a). Water diversion induced changes in aquatic biodiversity in monsoondominated rivers of Western Himalayas in Nepal: Implications for environmental flows. Ecological Indicators, 108, 105735. doi 10.1016/j.ecolind.2019.105735.

Shah, R.D.T., Sharma, S., Narayan Shah, D., \& Rijal, D. (2020b). Structure of benthic macroinvertebrate communities in the rivers of Western Himalaya, Nepal. Geosciences, 10(4), 150. doi 10.3390/geosciences10040150.

Sharma, S. (1996). Biological assessment of water quality in the rivers of Nepal. (Ph.D. thesis), University of Agriculture, Forestry and Renewable Natural Resources (BOKU), Austria.

Sharma, C.M., Sharma, S., Borgstrom, R., \& Bryceson, I. (2005). Impacts of a small dam on macroinvertebrates: A case study in the Tinau River, Nepal. Aquatic Ecosystem Health \& Management, 8(3), 267-275. doi 10.1080/14634980500218332.

Sharma, S., Nesemann, H., \& Pradhan, B. (2009). Application of Nepalese Biotic Score and its extension for river water quality management in the Central Himalaya. International Conference on Environment Energy and Water in Nepal: Recent Researches and Direction for Future. Kathmandu, Nepal.

Shrestha, J., Singh, D.M., \& Saund, T.B. (2009). Fish Diversity of Tamor River and Its Major Tributaries of Eastern Himalayan Region of Nepal. Nepal Journal of Science and Technology, 10, 219-223. doi 10.3126/njst.v10i0.2964.
Shrestha, K.K., Basnet, K., Bhandari, P., \& Gurung, M.B. (2016). Biodiversity assessment of the Mewa River Valley (Papung Corridor) Kangchenjunga Landscape, Taplejung, East Nepal. Report submitted to Kangchenjunga Landscape Conservation and Development Initiative (KLCDI), Nepal. International Centre for Integrated Mountain Development (ICIMOD).

Silva, E.C., Molozzi, J., \& Callisto, M. (2010). Size-mass relationships of Melanoides tuberculatus (Thiaridae: Gastropoda) in a eutrophic reservoir. Zoologia (Curitiba), 27(5), 691-695. doi 10.1590/S1984-46702010000500004.

Suren, A.M. (1994). Macroinvertebrate communities of streams in western Nepal: Effects of altitude and land use. Freshwater Biology, 32(2), 323-336. doi 10.1111/j.1365-2427.1994.tb0112 9.x.

Sweeney, B.W., \& Vannote, R.L. (1982). Population synchrony in Mayflies: A predator satiation Hypothesis. Evolution, 36 (4), 810-821.

Tamiru, S.M., Asfaw, S.L., \& Yilma, S.M. (2017). Correlation study of some physico-chemical parameters and benthic macroinvertebrates metrics on the ecological impacts of floriculture industries along Wedecha River, Debrezeit, Ethiopia. Journal of Coastal Life Medicine, 5(10), 433-440.

Thapa, A. (2015). A comparative study of fish and macroinvertebrate assemblages in headwater tributaries of glacial-fed and rain/spring-fed rivers in eastern Nepal. (BSc Thesis), Kathmandu University, Nepal.

Uy, C.J.C., Malicky, H., \& Bae, Y.J. (2018). Review of the filterfeeding caddisfly subfamily Macronematinae (Trichoptera: Hydropsychidae) in Southeast Asia. Raffles Bulletin of Zoology, 66, 664-703.

Vannote, R.L., Minshall, G.W., Cummins, K.W., Sedell, J.R., \& Cushing, C.E. (1980). The River Continuum Concept. Canadian Journal of Fisheries and Aquatic Sciences, 37(1), 130137. doi 10.1139/f80-017.

Wallace, J.B., \& Webster, J.R. (1996). The role of macroinvertebrates in stream ecosystem function. Annual Review of Entomology, 41, 115-139. doi 10.1146/annurev.en.41 .010196 .000555 .

WECS. (2011). Water Resources of Nepal in the Context of Climate Change. Water and Energy Commission Secretariat, Government of Nepal, Kathmandu.

Wohl, E. (2010). Mountain Rivers revisited. American Geophysical Union.

Woodward, G., Perkins, D.M., \& Brown, L.E. (2010). Climate change and freshwater ecosystems: Impacts across multiple levels of organization. Philosophical Transactions of the Royal Society B: Biological Sciences. 365(1549), 2093-2106. doi 10.1098/rstb.2010.0055. 